Original Research Paper

\title{
Why Construction Grammar Catches the Worm and Corpus Data can Drive you Crazy: Accounting for Idiomatic and Non- Idiomatic Idiomaticity
}

\author{
Thomas Herbst \\ Friedrich-Alexander-Universität Erlangen-Nürnberg, Germany
}

Article history

Received: 07-05-2015

Revised: 19-06-2015

Accepted: 19-06-2015

Email: support@thescipub.com

\begin{abstract}
This article outlines why the treatment of idiomatic elements in language in terms of constructions can be considered a real step forward in the understanding of the character of language. It is argued that construction grammar provides a theoretical basis for accommodating insights into the phraseological character of language that were gained in a number of fields such as corpus linguistics, foreign language teaching and traditional phraseology and lexicography.
\end{abstract}

Keywords: Collocation, Corpus Analysis, Construction, Contextualism, Electronic Dictionaries, Exemplar, Foreign Language Teaching, Idiom Principle, Learner's Dictionaries, Lexicography, Probabeme, Valency

\section{Introduction}

\section{Constructions}

Will the beginning of the 21 st century be looked upon by later historians of the subject as a turning point in the history of linguistics? At any rate, there seems to be a growing number of linguists who are attracted to theories sailing under such labels as construction grammar (Fillmore, 1988; Goldberg, 1995; 2006; Croft, 2013; Stefanowitsch, 2011a), usage-based approach (Tomasello, 2003; Bybee, 2010; Lieven, 2014) or cognitive grammar (Langacker, 1987; 2008a). These approaches (although, as indicated by the plural, by no means presenting a unified theory) have emerged as a sort of counterpoint to generative linguistics, i.e., the research instigated by the enormously influential ideas put forward by Noam Chomsky from the 1950s onwards. Both camps have in common that they explicitly address cognitive issues and that they are aiming at providing accounts of language acquisition, but they differ with respect to a large number of issues (concerning modularity, the role of derivations, the learnability of language, to name just a few). ${ }^{1}$

Usage-based researchers such as Boas (2011: 55-60), Bybee (2010: 22-28), Goldberg (2013: 15) or Lieven (2014) imagine language to consist of a network of constructions, which are stored in the constructicon on the basis of the input a speaker has, with frequency of occurrence being a relevant factor. The term construction has received a number of different interpretations; commonly it is described as a pairing of form and meaning, which is reminiscent of de Saussure's notion of the linguistic sign but, as Hoffmann (forthc.) points out, goes far beyond it. Goldberg (2006: 5) provides the following definition of construction:

\begin{abstract}
Any linguistic pattern is recognized as a construction as long as some aspect of its form or function is not strictly predictable from its component parts or from other constructions recognized to exist. In addition, patterns are stored as constructions even if they are fully predictable as long as they occur with sufficient frequency.
\end{abstract}

If we subscribe to Goldberg's (2006: 18) programmatic statement that "it's constructions all the way down", in other words, that a speaker's linguistic knowledge can be thought of entirely in terms of constructions, then it must be shown that all insights into the nature of linguistic phenomena can be accounted for in terms of constructions. ${ }^{2}$ If we want to demonstrate that Construction Grammar has a useful contribution to make to the learning and teaching of foreign languages, then we must show that a constructionist account of the linguistic phenomena central to foreign language learning provides us with insights that can be usefully applied to teaching methodology and the design of teaching materials.

The present article attempts to do this with respect to 
the phenomena of collocation and valency in English, both of which cause problems to foreign learners and both of which have received considerable attention in monolingual learners' dictionaries, for instance.

\section{Constructing idioms}

\section{Idioms}

Idioms in the classical sense present a prototypical case of constructions. Traditional definitions of idioms usually employ criteria such as semantic opacity or restrictions on formal realizations ${ }^{3}$ and Cruse (1986: 37) characterizes an idiom as "a lexical complex which is semantically simplex" ${ }^{4}$. Semantically, idioms are thus like words, which is why traditionally they are also subsumed under the category of lexemes (Lipka, 1992: 74). So what is to be gained by regarding them as constructions? As far as idioms which occur in only one formal realization - like bone idle, betwixt and between or put up with - are concerned, the only advantage is to put them on a par with other constructions. As soon as we look at the well-known phenomenon of variation in idioms, however, the constructionist approach has additional explanatory power. In the exemplar-based theory advocated by Bybee (2010: 19) every new input will, however minimally, modify a speaker's knowledge of their language, which means that frequency has an effect on storage and memory representation. Bybee (2013: 61) argues:

If each token of experience has an effect on representation, then each occurrence of the construction maps on the exemplar cloud of the construction.

This leads her to describe the "Resultative construction with drive" in the following way:

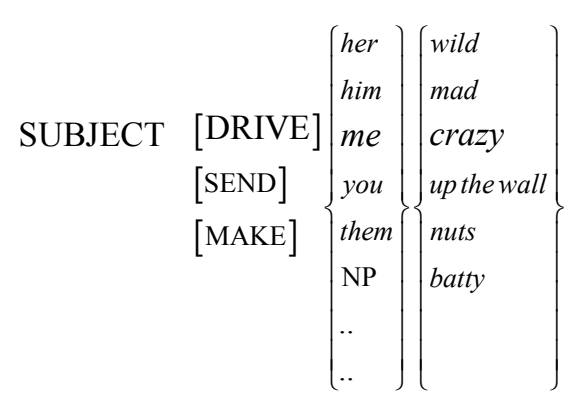

Bybee's (2013: 61) representation is intended to illustrate graphically that "items with higher token frequency within the construction serve as the central members of the categories that form for schematic slots within the construction". ${ }^{5}$ Data from the Corpus of
Contemporary American English show that drive $\forall(\forall=$ all morphological forms) me crazy (464 instances) is significantly more frequent than drive $\forall$ him batty ( 2 instances), for example: ${ }^{6}$

(1) a It's driving me crazy. <COCA: 2009 NEWS $>$

b The lore is that their theories drove them mad $\ldots<$ COCA: 2002 SPOK $>$

c Yet at the same time it sent her up the wall ... $<$ COCA: 2003 FIC >

Bybee's representation is very plausible, but may have to be modified in detail. Firstly, making a rather pedantic point perhaps, a characterization of the construction in terms of it containing "an adjective or prepositional phrase synonymous with crazy" (Bybee, 2013: 60) raises the question of whether one would really consider up the wall as a synonym of crazy anywhere outside this construction or an intransitive resultative construction: ${ }^{7}$

(2) a I literally went up the wall and carrying on, I mean, like sort of manic-depressive. $<$ COCA: 1990 SPOK>

b And I've got to get there on time, too, or Elise will go up the wall. $<$ BNC: JYC 2898>

The exemplar representation also entails that the "result" is a kind of 'negative state of emotion' so that you would not (in the near future, anyway) expect to find occurrences such as

(3) a My children's behaviour drives me very happy.

b Her exam results drove her to great satisfaction.

This only applies to drive, however, less so to send and not at all to make:

(4) If happiness means ambling through meadowland, alpine pastures and forest, then the 90 miles of footpaths here will send you ecstatic. $<$ BNC: ED1 341>.

(5) a I wake up to the clop-clop of horses' hooves on the cobbles in the morning. It makes me so happy. <BNC: J54 133-4>

b They go out to work and then come home and do the bloody housework. It makes me furious. $<$ BNC: CH6 8836-7>

c Dad rarely lets me watch TV Because it makes him mad. <BNC: G22 556>

This raises the question of whether $(5 c)$ should be analysed as an instance of this construction or whether 
one shouldn't rather argue that the meaning element of 'negative state of emotion' is entirely due to the adjective itself and that sentences with make can be seen as instances of the "general" resultative construction. ${ }^{8}$

Irrespective of detail, it has to be said that a treatment of idioms in terms of constructions (and exemplar representations) seems appropriate in many cases, the following may be cases in point:

(6) a This government can't see the wood for the trees. <BNC: FRS 2218>

b Unfortunately, too many people can't see the forest for the trees. $<$ COCA: 1994 NEWS $>$

c ... you can't see the trees for the forest. $<$ COCA: $2010 \mathrm{MAG}>$

d ... it gets to the point where you can hardly see the plants for the flowers. $<$ COCA: $1991 \mathrm{MAG}>$

In (6) not see the wood for the trees can be considered to be the central items of the construction, with the and for the being stable elements of the construction; similarly in (7) a slip of the is the fixed element with tongue and pen being central items of an exemplar representation:

(7) a When Bush talked of a Crusade... it was not a slip of the tongue. It was a mindset. <COCA: 2001 NEWS>

b In all the excitement the Registrar, Mrs Molly Croll, suffered a slip of the pen. And the Princess Royal's husband-to-be was wrongly named as Timothy Anthony Hamilton Laurence. <BNC: CBF 9720-1>

c A slip of the lip, or of the computer keyboard, can wipe out an American nuclear advantage almost instantaneously. <COCA: 1999 MAG>

In cases such as (6c) and (7c) speakers are probably being deliberately and consciously creative - thus proving Goldberg's (2013: 26) point that speakers "are at once impressively creative and impressively repetitive". This kind of creativity also shows in the case of the early bird-construction, which can be described as follows.

\section{[502]}

\begin{tabular}{l|l|l|l|}
$\begin{array}{l}\text { The early } \\
\text { bird }\end{array}$ & $\begin{array}{l}\text { catches } \\
\text { gets }\end{array}$ & the worm & $\begin{array}{l}\text { SEM: A person who } \\
\text { does something early } \\
\text { enough will } \\
\text { accomplish something. }\end{array}$
\end{tabular}

(8) a The early bird catches the voter. <BNC: K51 1683>

b The old saying is still valid: "The early bird catches the worm." The early photographer catches the best images. <COCA: 2010 ACAD> c The early bird goes to college. $<$ COCA: 2010 ACAD>

d We are pleased to offer an early bird festival saver ... <BNC: B3K 515>

e Early bird minimum, \$6; regular bingo $\$ 14$, for six face cards ... <COCA: 2012 NEWS $>$

All of these uses contain the word early as well as the meaning of 'accomplishment'. 'There are no examples of:

(9) a The early bird might have to wait for a long time.

b The early bird catches the flu.

It is probably impossible to determine exactly which part of an idiomatic expression has actually to be expressed for the meaning to be maintained (as is illustrated, I hope, by the title of this article). It is perfectly in line with the basic assumptions of usagebased approaches and Bybee's (2010) model in particular to say that idiom retrievability may also depend on individual hearers, their linguistic and cultural experience. Thus the following subtitle from a magazine article:

To tan or not to tan, that is the burning question. <BNC: G2V 2891>

may be easier to recognize as playing on a quotation from Hamlet than:

$$
\begin{aligned}
& \text { Man delights not Diana - nor woman either. } \\
& <\text { Lewis 5.1: 0:12>. }
\end{aligned}
$$

\section{Non-Idiomatic Idiomaticity: Sinclair's Idiom Principle}

While it is certainly true that we "shall do better to think in terms of a scale of idiomaticity" (Cowie and Mackin, 1975: x), the full extent to which language use is driven by factors that lie outside the realm of traditional or generative rules of grammar has only become apparent through the advent of corpus linguistics. The analysis of immense amounts of language text has revealed the immense amount of recurrent items that occur in actual language use (Altenberg, 1998). These insights have been formulated by Sinclair (1991: 110) in terms of the distinction between the open-choice and the idiom principle: ${ }^{11}$

It is clear that words do not occur at random in a text and that the open-choice principle does not provide for substantial enough restraints on consecutive choices. ...

The principle of idiom is that a language user has available to him or her a large number of semi- 
preconstructed phrases that constitute single choices, even though they might appear to be analysable into segments.

It is obvious that Sinclair's "semi-preconstructed phrases" qualify as constructions if frequency of occurrence is taken as a criterion for construction status. Sinclair (2004b: 46), analyzing the "phrase" on the of comes to the conclusion that "... on the brink of $\overline{\text { and }}$ on the verge of are commonly used as complex prepositions introducing mainly dreadful things". ${ }^{12}$

Identifying on the brink of as a chunk can be justified on the basis of corpus evidence: in the BNC the majority of the uses $(52 \%)$ of brink occur in the phrase on the brink of and a lower proportion (41\%) in COCA: ${ }^{13}$

$\begin{array}{lll}\text { BNC } & \begin{array}{l}\text { brink } \\ 409\end{array} & \begin{array}{l}\text { brink of } \\ 329\end{array} \\ \text { the } & 374 & 309 \\ \text { on the } & 240 & 214 \\ & & \\ \text { COCA } & \text { brink } & \text { brink of } \\ & 2647 & 1817 \\ \text { the } & 2356 & 1769 \\ \text { on the } & 1283 & 1078\end{array}$

Nevertheless, there is considerable structural flexibility, which is not due to semantic differences alone as the following examples show:

(a) Both "metaphorical" and "literal" uses occur in the phrase on the brink of:

(12) a In October-November 1962 the world seemed on the brink of nuclear war ... <BNC: HY8 1567>

b By nightfall, the rain that had started that morning was still whirling across the little town in New Jersey that lay on the brink of the Atlantic Ocean. <COCA 203 FIC $>$

(b) Both "metaphorical" and "literal" uses of brink occur in other constructions:

(13) a But would the United States go over the nuclear brink to save Britain, France, Germany or any other NATO member from a conventional attack? <BNC: ACS 1388>

b The sun was setting as she walked by the brink of the ocean. <BNC: GUM 4334>

(c) Brink in on the brink of behaves like a noun in occurring without article in newspaper headlines:

(14) UK on brink of revolution in telephone technology. <BNC: A3G 287>
Furthermore, although the great majority of corpus lines clearly support the view that (on) the brink of has a negative prosody, this is by no means always the case:

(15) a Seven points from four games in March against sides in the top six - Morton, St Mirren, Kilmarnock and Dunfermline - have taken Raith to the very brink of the Premier Division. $<$ BNC: K5J 3413>

b I can't help wondering if it's likely that a young man on the brink of a successful career and maybe planning marriage to another girl would ... <BNC: HNJ 942>

To what extent we should attribute Sinclair's "mainly dreadful things" to on the brink of can be tested by the inferences speakers are likely to make about which division a team are in when they came across an utterance such as:

They are on the brink of playing in League Two next season.

In the light of the evidence, a case is to be made out for an on the brink of-construction if - and presumably only if - frequency of occurrence is taken as a criterion because the uses of brink in other syntactic constructions do not play a different meaning from the one in on the brink of. Nevertheless, it can be considered a "prefabricated phrase" in Sinclair's sense, which is perfectly compatible with a Construction Grammar account. Describing the phenomena discussed above in terms of Construction Grammar is more appropriate than a classification as a "complex preposition" because it offers a better way of accounting for the variation to be found. The existence of such constructions can also be accounted for as the result of a grammaticalization process - similar to the developments which have led to a grammaticalized going to-construction, or further cases of (complex) prepositions or conjunctions (in accordance with, considering) and certain quantifier constructions (a great deal of). All of these units contribute to the idiomatic character as described by the idiom principle although they are non-idiomatic in the sense that there is no clear element of semantic unpredictability involved.

\section{Constructing valency}

\section{Valency and constructions}

Although verb valency is mostly seen as a grammatical phenomenon and not one that falls under the scope of idiomaticity, from the point of view of the foreign learner at least, there is a similar element of unpredictability: 
(17) a But I fail to understand your interest in all this. $<$ BNC: HWP 2423>

$\mathrm{b}$... we won't succeed in predicting new phenomena ... < BNC: A0T 1071>

In syntactic theory, valency theory is generally associated with projectionist accounts in that the valency of the verb is seen as determining the structure of the clause both with respect to the number and type of the complements it requires, which is why in the stemmata of Tesnière's (1959) dependency grammar it takes the highest position in the hierarchy. The perspective of valency approaches is to describe the valency of particular lexical units (Cruse, 1986: 24, 49). Valency dictionaries such as the pioneering Wörterbuch zur Valenz und Distribution deutscher Verben by Helbig and Schenkel ( $\left.{ }^{2} 1973\right), V A L B U$ (Schumacher, 2004) and the Valency Dictionary of English (Herbst et al., 2004) accordingly provide complement inventories of the respective valency carriers. However, they also relate these complements to syntactic patterns ${ }^{14}$. What one has to bear in mind is that the categories employed by traditional valency grammar (such as complement inventories) are abstractions over instances of language use, which is why a description of these phenomena seems perfectly compatible with a construction grammar approach. Indeed, the emergence of constructionist theories, in particular Adele Goldberg's theory of argument structure constructions, has given rise to different attempts of combining the two approaches (Welke, 2011; Engelberg et al., 2011; Stefanowitsch, 2011b, Faulhaber, 2011ab; Herbst, 2011b; 2014a; 2014b). In fact, there can be no doubt that valency relations can be captured in terms of constructions; in fact they could almost be seen as representing a prototype of item-based constructions as defined by MacWhinney (2005: 53): ${ }^{15}$

Item-based constructions open up slots for arguments that may occur in specific positions or that must receive specific morphological markings.

I use the term valency construction ${ }^{16}$ to refer to itembased constructions at a very low level of abstraction such as the following (see Herbst, 2014a: 181-187):

[503] [SCU: NP “GIVER"] give act_[PCU1: NP "GIVEE"]_[PCU2: NP “ITEM GIVEN"]

(18) If you wish, Lewis, I will give you the names and addresses of the three of them there that open all day. <BNC: HWM 867>

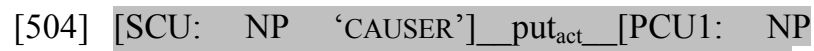
'AFFECTED']_[PCU2: PartP 'LOCATION: GOAL']
(19) a She put the book on the table. $<$ BNC: JYE 337>

b This puts you in a strong position to counterattack. <BNC: A0M 697>

Of course, these item-specific valency constructions can be related to the more general argument structure constructions of the Goldberg (2006) type. Such constructions have the obvious advantage of offering a convincing account of linguistic creativity (of the Pat sneezed the foam off the cappuccino-type). Assuming a level of item-based valency constructions seems necessary, too, however: As has been argued elsewhere (Faulhaber, 2011ab; Haugen, 2012; Herbst, 2011b), it does not seem possible to reliably predict a verb's behaviour on the basis of generalized argument structure constructions. This is why I have proposed that the principles Goldberg's (2006) model draws upon to account for the relationship between individual verbs and argument structure constructions they occur in - the Semantic Coherence Principle and the Correspondence Principle - should be supplemented by a Valency Realization Principle which is based on the concept of valency constructions (Herbst, 2014ab).

\section{Aspects of Meaning}

Our experience in the compilation of the Valency Dictionary of English (VDE) was that the degree of generalization possible with respect to a semantic characterization of the valency slots differed enormously between verbs. In a usage-based model, making use of a general label in one case and rather specific lexical representations in the other need not be considered an inconsistency (as it might be by reviewers of a dictionary), but rather it will be seen as a possible reflection of different degrees of abstraction arrived at by speakers of the language (knowledge about which will be subject to a certain amount of intuition as long as we have no reliable ways of testing such things). Thus - as in the case of Bybee's characterization of the "Resultative construction with drive" discussed above - the specification of valency constructions contains semantic descriptions of varying degrees of specificity, as in the following example (modelled on the basis of the VDE):

$$
\begin{aligned}
& \text { [SCU: NP 'AGENT']_catch } \text { act_[PCU: NP }_{\text {train/bus/flight/plane/etc.] }}
\end{aligned}
$$

(20) a I was in a hurry to catch the tube $\ldots<$ BNC: HWM 5>

b ... he'd walked back to Didcot Parkway Station at about five o'clock and caught the next train back to Oxford ... < BNC: HWM 864>

c ... he would originally have intended to catch the 11.30 from Paddington, arriving Oxford at 12.30. <BNC: HWM 525> 
A representation of the corresponding valency construction of catch in terms of [505] covers the different lexical strengths based on the token frequencies of the different nouns that can occur in the PCU-slot: ${ }^{17}$ An analysis of all occurrences of catch in the BNC using the dependency-based parser Treebank.info (Uhrig and Proisl, 2011) produces the following list of nouns occurring in the position of direct object (the PCU-slot of the construction): ${ }^{18}$

\begin{tabular}{llll}
\hline & & absolute frequency & log-likelihood \\
\hline 1. & glimpse & 284 & 5029.1201 \\
2. & sight & 351 & 4545.4544 \\
3. & eye & 485 & 4450.7239 \\
4. & breath & 186 & 2242.1227 \\
5. & fire & 184 & 1676.2246 \\
6. & train & 166 & 1674.2999 \\
7. & bus & 122 & 1219.8849 \\
8. & hold & 99 & 1211.3911 \\
9. & fish & 128 & 1117.2389 \\
10. & attention & 121 & 959.5919 \\
11. & imagination & 47 & 466.2234 \\
12. & plane & 46 & 382.8072 \\
13. & flight & 47 & 356.4835 \\
14. & cold & 30 & 334.5916 \\
15. & unaware & 17 & 313.2204 \\
16. & sun & 44 & 308.5382 \\
17. & ball & 45 & 292.9265 \\
18. & wrist & 28 & 286.4254 \\
19. & prey & 28 & 280.3183 \\
20. & whiff & 19 & 278.7109 \\
\hline
\end{tabular}

If valency constructions are defined as item-based low level constructions, then [501] - the "Resultative construction with drive" in Bybee's (2013) terminology - can be seen as an example of a valency construction. Goldberg (1995: 79) argues "there is a special sense of drive which only occurs in the resultative construction", which "constrains the result-goal argument to mean "crazy"'. The latter part of this statement is not entirely justified: it is certainly true that the uses of drive in (21) can be analysed in terms of a 'drive a car' sense, which must be distinguished from the 'resultative' sense of drive sb crazy and can also be found in other constructions: ${ }^{19}$

(21) a So Lewis drove down to the bottom of South Parks Road ... <BNC: HWM 1209>

b An hour later, as he drove the pair of them down to Oxford, Lewis felt strangely content. $<$ BNC: HWM 520>

However, the 'resultative' sense of drive does not always coincide with the argument meaning 'crazy', as shown by (22a-e) and (22f) might be analysed as representing this sense in the Caused Motion Construction: ${ }^{20}$

(22) a Why? - that is what I asked myself. Or rather that is not, in the first instance, what I asked myself, because I was driven to the view incorrectly — that there could be no link between the two crimes. <BNC: HWM: 3083-4)

b His constant invasion of her privacy was driving her to distraction. <BNC: H9V 979>

c The thought drove him to despair and drink. $<$ BNC: B1X 2315>

d Emotions drive the horse into behaviour which will increase its chances of survival. $<\mathrm{BNC}$ : ADF $526>$

e Life had become completely incoherent, driving him deeper into, not away from, his despair ... $<$ COCA: 1996 FIC $>$

f $\mathrm{Mr}$ Parsons drove a flock of sheep into the house ... <BNC: AB4 73>

It thus seems that the meaning of [501] cannot be attributed to a special sense of drive alone, at least not without violating one of the guiding principles of Goldberg's approach, namely that of avoiding implausible verb senses (Goldberg, 1995: 9). This means that interaction of the meanings of the construction and the words occurring in an expression is much more complex than most models envisage - and that corpus data can drive you crazy!

Or make you sick: as soon as one considers the fact that, as pointed out above, there is no real case to be made out for including make in this particular construction at all since

(23) It was a mind-boggling task. It was making her crazy. <BNC: H97 1891>

seems to be a perfectly straightforward case of a use of make and crazy in the resultative construction. Interestingly, a Treebank.info-based search of the BNC produces only 4 instances of crazy and a wide range of further adjectives. In order to increase the comparability of the data, a search with only personal pronoun objects was carried out: for drive, this produces a relatively restricted number of adjectives, for make more than $900 .^{21}$ The following table shows the frequency for 28 adjectives in the resultative construction with a personal pronoun object and drive (9 altogether) and make (top 20) in the BNC (based on a treebank.info search) and in COCA: 


\begin{tabular}{|c|c|c|c|c|}
\hline \multirow[b]{2}{*}{$\begin{array}{l}\text { me|you|her| } \\
\text { him|them|us }\end{array}$} & \multicolumn{2}{|c|}{ drive $\forall$} & \multicolumn{2}{|c|}{ make $\forall$} \\
\hline & $\begin{array}{l}\text { BNC } \\
\text { pmw }\end{array}$ & $\begin{array}{l}\text { COCA } \\
\text { pmw }\end{array}$ & $\begin{array}{l}\mathrm{BNC} \\
\mathrm{pmw}\end{array}$ & $\begin{array}{l}\text { COCA } \\
\text { pmw }\end{array}$ \\
\hline happy & & & 1.53 & 3.39 \\
\hline sick & & & 1.26 & 2.03 \\
\hline aware & & & 1.16 & 0.78 \\
\hline angry & & & 1.13 & 1.18 \\
\hline nervous & & & 0.70 & 1.59 \\
\hline vulnerable & & & 0.61 & 0.38 \\
\hline uneasy & & & 0.46 & 0.42 \\
\hline $\operatorname{mad}$ & 0.65 & 0.24 & 0.38 & 1.05 \\
\hline comfortable & & & 0.36 & 0.37 \\
\hline different & & & 0.35 & 0.40 \\
\hline unhappy & & & 0.34 & 0.23 \\
\hline attractive & & & 0.33 & 0.11 \\
\hline popular & & & 0.31 & 0.16 \\
\hline suitable & & & 0.30 & 0.07 \\
\hline likely & & & 0.28 & 0.03 \\
\hline uncomfortable & & & 0.27 & 1.08 \\
\hline responsible & & & 0.27 & 0.13 \\
\hline sad & & & 0.26 & 0.89 \\
\hline difficult & & & 0.26 & 0.17 \\
\hline suspicious & & & 0.25 & 0.2 \\
\hline crazy & 0.34 & 2.09 & 0.03 & 0.58 \\
\hline insane & 0.13 & 0.16 & & 0.03 \\
\hline wild & 0.03 & 0.11 & 0.02 & 0.03 \\
\hline daft & 0.02 & & & \\
\hline bonkers & 0.01 & 0.02 & & \\
\hline crackers & 0.1 & & & \\
\hline quackers & 0.1 & & & \\
\hline furious & 0.1 & & 0.09 & 0.16 \\
\hline
\end{tabular}

The much more general meaning of make in comparison to drive accounts for a great number of the differences to be observed. What needs to be explained, however, is why - despite the fact that both make and drive can be used in the resultative construction with some adjectives expressing states of emotion such as mad and crazy - there are practically no instances of drive with semantically similar adjectives such as angry, nervous and especially furious:

(25) a People like you make me mad! <BNC: JY5 1631>

b You drive me mad. <BNC: CA3 2556>

(26) a Quite simply, it makes me furious. <BNC: G1A $621>$

b ? It drives me furious.

\section{Meaning as an emergent property}

The above discussion raises the question of verb meaning and how speakers arrive at the meanings of verbs. If we consider grammar to be emergent, then surely meaning is as well. This is perfectly in line with Ambridge and Lieven's (2011: 101) view that the "meaning of the word continues to be refined through childhood and - for most words - presumably into adulthood. ${ }^{22}$ Let us speculate about the verb meet for a minute: The overwhelming number of corpus examples are of the Person A meets person B type:

(27) a But he is coming to meet me. <BNC: HWM 1194>

b I'm meeting Lucy off the train later on anyway $\ldots<$ BNC: HWM 1322>

c One night in Chipping Norton I met a married woman and fell deeply in love with her. $<$ BNC: HWM 1376>

It is more than reasonable to assume that language learners will encounter this prototypical use first and form a hypothesis about the meaning of meet on that basis. In fact, evidence from the CHILDES-database (MacWhinney, 2000) shows this relatively clearly: of 118 occurrences of meet $\forall$, the majority corresponds to the prototype identified ${ }^{23}$, but - interestingly - there are also several examples in which meet is used with respect to animals, toys etc.:

(28) a Pat 's off on his delivery round meeting lots of friends along the way <CHILDES: Thomas t2 $0810>$

$\mathrm{b}$ the breakdown truck 's met the postvan $<$ CHILDES: Thomas t3 07 04>

c ... we were reading the tale of Tom Kitten and they meet the family of puddle ducks $<$ CHILDES: Thomas t3 00 02>

There are quite a few examples that are different in character, however. Example (29) differs from the previous ones in that the verb is used monovalently and thus requires a plural subject, but one would hardly argue that it represents a different sense:

We have met before. <BNC: HWM 2055>

This is different in the case of the following examples, which are not covered by the Person A meets Person B pattern:

(30) a Did someone meet the train, Inspector? $<\mathrm{BNC}$ : HWM 2258>

b Carriages met every train in order to bring the visitors to the mansion ... <BNC: B7C 1965>

c Then her sad eyes met Morse's ... <BNC: HWM 1549>

In terms of the exemplar model outlined above, it can be assumed that every new use that a speaker (or foreign language learner) encounters widens their concept of the meaning of the verb meet. Examples not corresponding to the prototype may not even have to occur frequently 
because by differing from the prototype they are particularly salient. Nevertheless, all the uses of meet mentioned above can be subsumed under a general semantic label such as 'coming together'.

However, a treebank analysis (Uhrig and Proisl, 2011) of all nouns and pronouns occurring as direct objects in the BNC reveals that the top three noun collocates do not denote people at all - need (1287 hits), requirement (587) and demand (520) - him, however, has 976 hits. $^{24}$

(31) a North and South Planners in Sweden and India think their countries can meet their energy needs, cut emissions of greenhouse gases and get richer by the end of the century <BNC: ANX 33>

$b$ The current engine meets all emissions requirements ...<BNC: A6X 60>

c If they don't meet the deadline, the implications for the environment and the economy could be devastating. $<$ COCA: 2005 SPOK $>$

Such uses can be analysed as representing a separate sense of meet if the lexical items filling the PCU-slot of the corresponding valency construction are taken into account. This results in a valency construction such $\mathrm{as}^{25}$ :

\section{[506] [SCU: NP 'SUBJECT'] meet act_[PCU: NP} need/requirement/demand/etc. | SEM: fulfill]

This type of constructivist representation corresponds to the description provided in the Valency Dictionary of English (Herbst et al., 2004), where the specification of the corresponding formal valency pattern is accompanied by a semantic description of the following kind:

Someone or something that meets a demand, certain expectations or requirements fulfils them.

\section{Constructing collocations}

Provided a description valency constructions in a way similar to the one proposed in [506], i.e. in terms of a lexical characterization of certain slots is adequate, then this raises the question of where to draw the line between valency and collocation. Traditionally, the distinction is based on two different types of cooccurrence relations: In the one case, valency, we are dealing with the co-occurrence of lexical units with grammatical units, in the other, collocation, with the cooccurrence of several lexical units. Constructions such as [506] are blurring this distinction, which is very much in line with the basic assumption of a lexicogrammatical continuum central to constructionist approaches but also to the work of Sinclair (2004a: 164-165), for example.

It is worth noting that the term collocation has received the same kind of reinterpretation as the term construction. As with the original view of constructions
(Goldberg, 1995), there is a view of collocational research that focuses on the aspect of unpredictability, a position which can be associated with foreign language linguists and lexicographers such as Cowie (1994) or Hausmann (1984; 2007), Lea (2007) or also Gilquin (2007). The frequency aspect, on the other hand, features prominently in the use of the term collocation in corpus linguistics, notably by Sinclair (1991). Both types can be accounted for in terms of constructions. Bybee (2010: 28) refers to the latter type and Firth's (1957: 196) example of dark night as "conventionalized instances or exemplars of constructions that are ... known to speakers as expressions they have experienced before."26

The question of unpredictability is linked with that of representation of valency constructions. From a foreign learner's point of view, there can be no doubt that the following examples are unpredictable and it is from this point of view that Hausmann's (1985) distinction between a semantically autonomous base (Basis) and a semantically "empty" collocate (Kollokator) seems justified:

(32) a English catch a/theletc. train vs. German einen/den/etc. Zug erwischen

b English attend to a/the/etc. problem vs. German sich eines/des/etc. Problems annehmen

c English award a prize vs. German einen Preis verleihen

$\mathrm{d}$ English meet a deadline vs. German eine Frist/einen Termin einhalten etc.

If we take valency constructions such as [505] and [506] to be part of a native speaker's knowledge of their language, then possible collocates are already part of that description. This would not be the case in the same way if the valency description were to be stated in terms of a generalization such as [507] (for catch):

\section{[507] [SCU: NP 'AGENT']_catch act_[PCU: NP 'MEANS OF PUBLIC TRANSPORT']}

Whether this needs to be taken as an argument in favour of a description of valency complement slots in terms of (highly frequent) lexical elements or in terms of generalizations, is difficult to say. Generalizations, as was pointed out above, may play an important role with respect to creativity since it would be naïve to expect speakers only to use verb-noun combinations they have come across before.

Thus, there is a case to be made for generalized characterizations of verbal valency slots from the point of view of using the verb and a case in terms of an exemplar representation from the point of view of the PCU-element of the construction (the direct object of 
catch or meet). For a usage-based approach this does not present a problem, however,: ${ }^{27}$

Once a generalization is formed or the generalization is made, the speaker does not necessarily have to throw away the examples upon which the generalization is based. If linguistic memory is like memory for experience in other domains, it is unlikely that specific instances are completely discarded once a generalization is made ... . (Bybee, 2010: 15)

Obviously, that if we assume that children "acquire the lexicon through and in the constructions in which they occur" (Behrens, 2011: 382; my translation) ${ }^{28}$, then this involves storage of valency constructions as well as collocations.

\section{Non-Idiomatic Idiomaticity - "Normal Ways of Saying Things"}

The research tools currently available have put linguists in a position to study relations between the words and other words and the syntactic constructions of a language on an unprecedented scale. One aspect of idiomatic language use is much more difficult to capture, however and that is how particular meanings are expressed in particular languages and whether it is actually the same meanings that are expressed in different languages.

Imagine a situation in which the father of the family is busy working in his study and suddenly the doorbell rings. How likely is he to say to his son or daughter:

(33) a Can you go on/at/by the door, please?

b Kannst du bitte die Tür beantworten?

Both sentences come close enough to being incomprehensible to provide a complacent teenager with an excuse for refusing the request. However, it is difficult to see the reasons for this in the light of the following parallels between the uses of these verbs in both languages:

(34) a She was on the phone and he stood silently, filling the doorway, raising an eyebrow at her. $<$ BNC: AB9 28>

b Gegenüber steht der Schreibtisch ihrer Kollegin, mit der sie sich den Job teilt. Sybille Hartmann ist am Telefon. Ihr Gesicht und die Beine sind vom Wochenende im Garten gebräunt. <DWDS: Die Zeit 2006>

(35) a 'A Mr Tracey is on the phone,' she said. $<$ BNC: HTR 1335>

b Gerhard Schröder ist am Telefon ... < DWDS: Die Zeit 2013>
(36) a In any case she didn't answer my question. $<$ BNC: A0U 44>

b Er hat alle meine Fragen beantwortet. $<$ DWDS: Die Zeit 2009>

What makes such examples interesting is that neither answer the door/phone nor ans Telefon/an die Tür gehen would be analysed as an idiom on the grounds of any unpredictability. What is idiomatic about them is not their internal semantics, but the fact that they are used to refer to a particular type of situation.

Langacker (2008b: 28) talks of "countless units representing normal ways of saying things" - a point that has also been brought to attention by Pawley and Syder (1983: 196), for instance. One might argue that differences in established use in two languages such as those in (33) are an indication of different conceptualizations in the two languages: that the same action is conceptualized in English as a reaction to something and as an action (implicitly caused by a stimulus) in German. Note, however, that - within the limits of established use speakers do not really have much choice.

In other cases, there is choice: to refer to a group of two or three people in English, speakers can choose between the two/three of us and we two/three, in German, there is not (wir drei); to refer to a period of roughly 183 days, speakers can choose between six months - sechs Monate and half a year-ein halbes Jahr in English and in German. ${ }^{29}$ However, there are differences in frequency: ${ }^{30}$

$\begin{array}{lll} & \text { BNC } & \text { COCA } \\ \text { six months } & 3806 & 15410 \\ 6 \text { months } & 199 & 1455 \\ \text { half a year } & 46 & 300\end{array}$

The German DWDS-corpus (Kernkorpus 20, Deutsches Textarchiv and DIE ZEIT) shows a slight preference for halbes Jahr:

$\begin{array}{llll} & \text { DWDS } & \text { DWDS } & \text { DWDS } \\ & \text { Kern 20 } & \text { Text-archiv } & \text { Die Zeit } \\ \text { sechs Monate } & 1043 & 459 & 7912 \\ \text { 6 Monate } & 466 & 202 & 166 \\ \text { halbes Jahr } & 1120 & 885 & 9203\end{array}$

Such differences in frequency can be interpreted in two ways: one is that if native speakers want to refer to the time span in question, there is a fifty per cent chance that this will happen by sechs Monate or halbes Jahr in German, but in English there is a chance of 1 in 70 for it to be half a year (assuming for a minute that the corpora are fully representative of language use in Britain and in Germany, which of course they are not). The other is that 
there are differences between six months and half a year in terms of their (semantic and/or pragmatic) meaning. There certainly are - in that even in German it would be rather unusual to use halbes Jahr to refer to the stage of pregnancies, for example. Nevertheless, it is highly unlikely that there should be such a great difference in the number of situations in which in German sechs Monate is more appropriate than halbes Jahr and those in which in English six months is more appropriate than half a year. Would it not make sense to assume that in such cases there is considerable semantic overlap between two constructions and that in this area six months tends to be used in English whereas halbes Jahr and sechs Monate are equally likely to be used in German? In this case, the situation could - in an obviously oversimplified way - be described as follows:

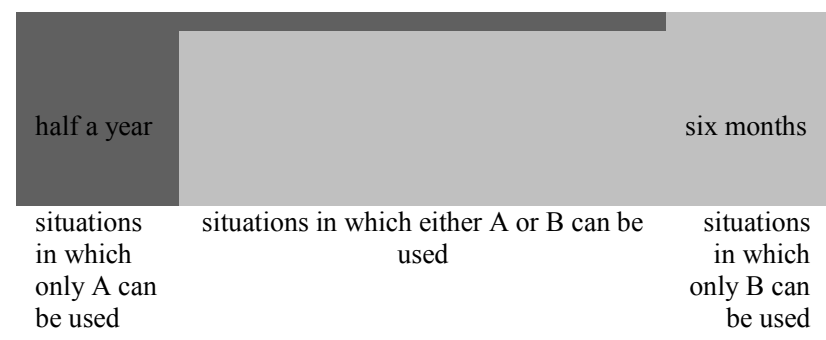

half a year and six months in English.

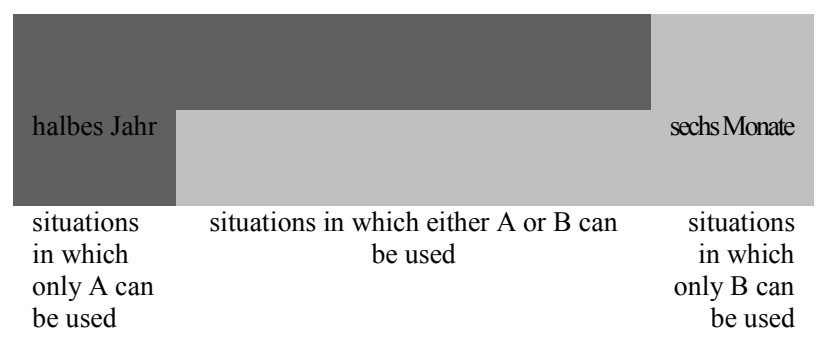

halbes Jahr and sechs Monate in German.

Despite the difficulties in determining whether a particular use of a construction is due to its meaning or whether in the context given another construction could also be used, the factor of the probability of construction A being preferred over construction $\mathrm{B}$ must be taken into account in a usage-based Model:

Because grammar is based on usage, it contains many details of occurrence as well as a record of the probabilties of occurrence and co-occurrence. (Beckner et al., 2009: 5)

Differences in frequency between synonymous or near-synonymous prefabs can also be found between different varieties of the same language, as has been shown by Mittmann (2004) in a large-scale analysis of multi-word clusters in two corpora of spoken British and American English. ${ }^{31}$

$\begin{array}{lll} & \text { LSAC ppm } & \text { BNCSD ppm } \\ \text { kind of } & \mathbf{1 3 6 8 . 0 8} & 118.1 \\ \text { sort of } & 370.12 & \mathbf{1 0 4 4 . 4 1} \\ & & \\ & \text { LSAC ppm } & \text { BNCSD ppm } \\ \text { a bit } & 54.04 & \mathbf{1 1 9 9 . 7 7} \\ \text { a little } & \mathbf{9 5 9 . 4 8} & 454.94 \\ \text { a little bit } & \mathbf{3 0 0 . 3 1} & 144.9\end{array}$

If we want to account for idiomaticity - including "normal ways of saying things" - then quantitative data of this kind will also have to be part of the story.

\section{Foreign Language Teaching}

\section{Units of Meaning in Foreign Language Teaching}

It is obvious that the insights into the role and character of different types of constructions should be reflected in language teaching, in particular also the teaching of foreign languages. ${ }^{32}$ If "the acquisition of grammar is the piecemeal learning of many thousands of constructions and the frequency-biased abstraction of regularities within them" (Ellis, 2003: 67), then the input learners receive is crucial. ${ }^{33}$ This concerns both the selection of items to be taught and their presentation in textbooks and dictionaries.

If concepts that have been identified as being instrumental in first language learning such as entrenchment and pre-emption (Tomasello, 2003) play a role in foreign language learning as well, the obvious consequence must be to provide adequate exposure to the relevant units. This means, for example, that constructions such as the [the_NUM_of_PERSPRON]construction (the two etc. of $\overline{u s}$, which is by far more frequent than we two etc.)(Herbst, forthc.) should be introduced relatively early on so that they can become entrenched or that, for instance, six months should occur in texts soon after the word year has been introduced. ${ }^{34}$

\section{Units of Meaning in Dictionaries}

It is equally obvious that dictionaries must find adequate ways of representing the phraseological nature of language. This is not an entirely trivial task since dictionaries, as is obvious from their equivalents in other Germanic languages such as woordenboek, ordbok, Wörterbuch etc. - are about words and traditionally the overall structure of most dictionaries is based on the notion of "single-word" words. Nevertheless, it must be said that the insights gained by corpus linguistics have resulted in an enormously improved coverage of multi-word constructions in monolingual learner's dictionaries of English, for example. ${ }^{35}$ Cases such as six months can be covered rather well in (good) bilingual dictionaries: they very often contain phrases in bold type with translation equivalents not containing the equivalent given for the headword as such: 
Jahr ... year; die20er/30er- e etc. the twenties/thirties etc ... ein halbes $\sim$ six months, half a year $<$ PONS Großwörterbuch 2002 $>$

In this context, Herbst and Klotz (2003) introduce the term probabeme for a phrase such as six months to indicate the fact that these units represent the most likely equivalent in cases in which the headword occurs in certain combinations.

\section{Units of Meaning in E-Dictionaries}

The alphabetical structure of the prototypical print dictionary poses obvious problems with respect to the integration of multi-word units: should an idiom such as The early bird catches the worm be listed under the (which would result in a rather long entry for the), under early (first "content word"), bird (first noun), catch (and get) or worm? Should of course be given under of or course or be listed as a separate entry?

The technology underlying electronic dictionaries, it would seem, should enable lexicographers to design new access options that overcome the obvious shortcomings of print dictionaries in this respect. The following sample shows that there are great differences between high-quality dictionaries available online at the time of writing:

Multi-word expressions in online dictionaries ${ }^{36}$

\begin{tabular}{|c|c|c|c|}
\hline ODCIE lemma & $\begin{array}{l}\text { Longman Dictionary of } \\
\text { Contemporary English } \\
\text { LDOCE-online }^{35}\end{array}$ & $\begin{array}{l}\text { Oxford Advanced } \\
\text { Learner's Dictionary } \\
\text { OALD9-online }\end{array}$ & $\begin{array}{l}\text { Macmillan Dictionary } \\
\text { MEDAL-online }\end{array}$ \\
\hline $\begin{array}{l}\text { the early bird catches } \\
\text { the worm }\end{array}$ & $\begin{array}{l}1 \text { search for expression } \rightarrow \text { "no result" } \\
2 \text { search for "bird" } \rightarrow \text { lemma list } \\
3 \text { choose bird noun } \\
4 \text { scroll down to cross-reference "early bird" } \\
5 \text { click on cross-reference "early" } \\
6 \text { result in entry of "early" } 10\end{array}$ & $\begin{array}{l}1 \text { search for expression } \rightarrow \\
\text { immediate result }\end{array}$ & $\begin{array}{l}1 \text { search for expression } \rightarrow \\
\text { immediate result }\end{array}$ \\
\hline of course & 1 search for expression $\rightarrow$ entry "of course" & $\begin{array}{l}1 \text { search for expression } \rightarrow \\
\text { entry "course of action" } \\
2 \text { search for "course" } \rightarrow \\
\text { "course noun" } \\
3 \text { scroll down to "idioms" } \\
\text { subentry "of course" }\end{array}$ & $\begin{array}{l}1 \text { search for expression } \rightarrow \\
\text { immediate result }\end{array}$ \\
\hline keep in touch (with) & $\begin{array}{l}1 \text { search for "keep in touch" } \rightarrow \text { "no result" } \\
2 \text { search for "in touch" } \rightarrow \text { "no result" } \\
3 \text { search for "touch" } \rightarrow \text { lemma list } \\
4 \text { choose "touch noun" } \\
5 \text { scroll down to } 3\end{array}$ & $\begin{array}{l}1 \text { search for expression } \rightarrow \\
\text { immediate result }\end{array}$ & $\begin{array}{l}1 \text { search for "keep in } \\
\text { touch" } \rightarrow \text { immediate result }\end{array}$ \\
\hline keep an eye on & $\begin{array}{l}1 \text { search for expression } \rightarrow \text { no result } \\
2 \text { search for "keep" } \\
3 \text { choose "keep verb" } \\
4 \text { scroll through entry } \rightarrow \text { no result } \\
5 \text { search "eye" } \rightarrow \text { lemma list } \\
6 \text { scroll to } 3\end{array}$ & $\begin{array}{l}1 \text { search for expression } \rightarrow \\
\text { immediate result }\end{array}$ & $\begin{array}{l}1 \text { search for expression } \rightarrow \\
\text { immediate result }\end{array}$ \\
\hline to the point & $\begin{array}{l}1 \text { search for expression } \rightarrow \text { no result } \\
2 \text { search for "point" } \rightarrow \text { lemma list } \\
3 \text { choose "point noun" } \\
4 \text { scroll down to } 2 \text { (bold type in glossed example) }\end{array}$ & $\begin{array}{l}1 \text { search for expression } \rightarrow \\
\text { immediate result }\end{array}$ & $\begin{array}{l}1 \text { search for expression } \rightarrow \\
\text { immediate result }\end{array}$ \\
\hline be in for & $\begin{array}{l}1 \text { search for expression } \rightarrow \text { no result } \\
2 \text { search for "in for" } \rightarrow \text { no result } \\
3 \text { search for "in" } \rightarrow \text { lemma list } \\
4 \text { choose "in preposition" } \rightarrow \text { not found } \\
5 \text { choose "in adjective" } \rightarrow \text { not found } \\
6 \text { choose "in adverb" } \\
7 \text { scroll down to } 11\end{array}$ & $\begin{array}{l}1 \text { search for expression } \\
2 \text { choose "be in for } \\
\text { something" } \rightarrow \text { result }\end{array}$ & $\begin{array}{l}1 \text { search for expression } \rightarrow \\
\text { immediate result }\end{array}$ \\
\hline be in charge of & $\begin{array}{l}\text { 1 search for expression } \rightarrow \text { no result } \\
\text { 2. search for "in charge of" } \rightarrow \text { no result } \\
\text { 3. search for "charge of" } \rightarrow \text { entry "Charge } \\
\text { of the Light Brigade, the" } \\
\text { 4. search for "in charge" } \rightarrow \text { no result } \\
\text { 5 search for charge } \rightarrow \text { lemma list } \\
\text { 6. choose "charge noun" } \\
\text { 7. scroll to } 2\end{array}$ & $\begin{array}{l}1 \text { search for expression } \rightarrow \\
\text { "sorry no search result" } \\
2 \text { search for "in charge of" } \rightarrow \\
\text { "sorry no research result" } \\
3 \text { search for "charge of" } \rightarrow \text { "the } \\
\text { Charge of the Light Brigade" } \\
4 \text { search for "in charge" } \rightarrow \\
\text { no result } \\
5 \text { search for "charge" } \\
6 \text { scroll down to sense } 5 \\
\text { (collocation in example) }\end{array}$ & $\begin{array}{l}1 \text { search for expression } \rightarrow \\
\text { no result; lemma list } \\
\text { inclding "in charge of" } \\
2 \text { choose "in charge of" }\end{array}$ \\
\hline
\end{tabular}


This survey, which, of course, is far too small to allow any conclusions as to the overall quality of the three dictionaries, shows that the potential of the electronic medium has been exploited in varying degrees. The Macmillan Dictionary has by far the best access structure in that the multi-word expressions searched for almost immediately produced the desired result. In cases where the expression is part of a larger entry, the remaining entry can be accessed simply by scrolling. The Oxford Advanced Learner's Dictionary is almost as user-friendly as the Macmillan Dictionary but takes one to the appropriate entry rather quickly in most cases. The Longman Dictionary of Contemporary English, however, which in its print version (LDOCE 5, LDOCE 6) puts great focus on multi-word expressions, lacks - at least in the sample analysed - an equally appropriate access structure to multi-word units in its online version.

From a foreign language user's perspective the fact that OALD9 does not take one immediately to the appropriate entry for of course is highly irritating. ${ }^{37}$ However, a learner who encounters sentences such as:

(37) a 'Look, if there's anything at all you think I ought to know ...' <BNC: HWM 468>

b He wasn't waiting on the Oxford platform at all. $<$ BNC: HWM 2391>

and wonders what at all means will be taken to the correct entry by typing in "at all" in the Macmillan Online-Dictionary, OALD9-online takes one to "(not) at all" in the entry for all, whereas LDOCE displays "no result" (which is not true because under all sense 5 there is a perfectly good explanation of the uses of at all). It is very obvious that, ideally, the search for a multi-word expression should immediately take the user of an online dictionary to the respective entry, which entails that a search for "at all" should take the user to at all as well as (not) at all - which major entry these subentries are a part of is relatively irrelevant. Basically, this kind of structure still reflects features of the print dictionary which are a hindrance rather than a help in finding the information one is looking for in such cases. For obvious reasons, the principle of alphabetical order is unavoidable in most types of print dictionary, but the electronic medium should offer more flexibility.

\subsection{Towards a Learners' Constructicon}

Computers have enabled us to analyse language in a way which fifty or sixty years ago was "considered impossible" or "marginally possible but lunatic" by many (Sinclair, 1991: 1); it is about time that we made computers present language in ways which by some may be considered "possible but lunatic" today: it is relatively obvious that lexicography is heading in the right direction, but we definitely have not yet reached the end of the road towards a dictionary - or a lexicogrammar or a reference constructicon (?) - which really implements the idea of a network of constructions in a way that traditional print dictionaries never could.

Faster access to the lexical unit in question is definitely a desideratum, as the examples above have shown. It is certainly an important step forward towards increased user-friendliness if a search for "bird catches", however unorthodox it may seem, takes you directly to the early bird catches the worm (as is indeed the case in the Macmillan Dictionary and OALD9-online). But could it not be a consequence of constructionist thinking to give up some of the firmly established traditional classifications?

Let me give two examples: for a verb such as decide, for example, both the Macmillan Dictionary and OALD9online provide a very clear indication of the valency patterns of decide (which together with the definitions given can be interpreted as valency constructions). However, both dictionaries treat decide on as a phrasal verb, the Macmillan Dictionary decide against as well. This means that uses such as the following, which according to valency theory are all valency patterns of decide (Herbst and Schüller, 2008), are not to be found in the same section of the dictionaries.

(38) a ... Morse decided to view Parson's Pleasure by daylight. $<$ BNC: HWM 1208>

b But he decided against it. $<$ BNC: HWM 1701>

c ... Wycliffe decided on a walk ... . <BNC: HWP 2316>

The phrasal verbs are given in subentries - in the case of OALD9-online one has to scroll down past the sections WORD FAMILIES, WORD ORIGIN and EXTRA EXAMPLES. Since decide against and decide on are prepositional verbs according to the definition of Quirk et al. (1985: 11501168 ) and not phrasal verbs because the particle cannot be shifted, there is no linguistic justification for treating them differently from decide that-clause or decide to do or, for that matter, decide between, which both dictionaries include in the main entry. It is difficult to see what is to be gained from being taken to that phrasal verb subentry in a search for "decide on" without being shown the far more frequent uses with a that-clause or an infinitive, when "decide that" or "decide between" produces no result. Just as it makes sense from a construction grammar point of view that ("grammatical") valency patterns and ("lexical") collocations are indicated in the same way (e.g. by bold type) (see 2.3 above), one could throw such unnecessary distinctions as that between multi-word verbs ("lexical") and other valency patterns ("grammatical") overboard.

Another case in point is presented by word class labels or part of speech distinctions in general. While part of speech labels such as noun, verb or adjective express certain generalizations that all words assigned to these classes have in common, this does not apply in the same way to classes such as determiner, pronoun or adverb or preposition and conjunction. Furthermore, it 
must be doubted whether such part of speech labels can be interpreted by many users. In a test with 75 first semester university students of English, Faulhaber et al. (2013: 7679) found that only $11 \%$ were able to interpret the word class label det for the novel word tilc in a mock dictionary entry in a way that would lead them to classify a sentence in which tilc was used as a pronoun (tilc of them) as ungrammatical. Thus it must be doubted whether a menu distinguishing between different word classes in the case of words such as to (where LDOCE-online offers " to $^{1}$, to ${ }^{2}$ preposition, to 3 " adverb) or both ("both" determiner, both ${ }^{2}$ conjunction in LDOCE-online) guarantees fast access. If electronic dictionaries were to provide a list of different uses for such function words without giving a word class label at all, this might be more of a help for the user of the dictionary. Furthermore, such a policy would certainly be in line with the idea of grammatical categories as emerging from a network of uses.

\section{Concluding Remarks}

A question that might be asked with some justification is whether a construction grammar account of idioms, collocations and valency patterns provides us with any new insights - and the answer presumably has to be that it depends on what you mean by new. It is certainly true that construction grammar offers a framework that is able to model, for instance, the variability of idioms rather nicely, but it would be totally wrong to say that the phenomenon as such would not have been recognised in more traditional accounts of phraseology. If we take the excellent Oxford Dictionary of Current Idiomatic English (volume 1, 1975, by Cowie and Mackin; volume 2, 1983, by Cowie, Mackin and McCaig), there is an entry for an early bird and one for the early bird catches the worm, the latter of which contains the following indications of variation:

the early bird catches the worm (saying) the person who seizes the earliest opportunity of doing sth (eg getting up before others, reacting faster than others to a situation, etc) will get what he wants, be successful at the expense of others etc $\square$ (music hall song) She was one of the early birds | And I was one of the worms. $\square$ (NONCE) At eleven o'clock in the morning I was certainly no early bird---but the plan still looked fair enough to catch some sort of worm. PP $\square$ 'The early bird gathers the worm,' Mother was saying, and it would be best, if I was to cut new ground, to set out rather early. MM $\square$ usu. comment or recommendation to act; sometimes in the construction it's the early bird (who/that) catches the worm.

Similarly, the collocational character of set the table and set the alarm are covered both by the Valency
Dictionary of English (in the entry of set) and collocation dictionaries such as the Oxford Dictionary of Collocations (under table and alarm respectively):

set verb ...

Set can mean 'place or put'. A person' ${ }^{\mathbf{I}}$ can set ...

(ii) the table $\mathrm{e}^{\text {II }}$, i.e. place cutlery, etc. on it.

(iii) something such as a clock or an alarm ${ }^{\text {II }}$, i.e. adjust it to the right time.

table noun ...

VERB + TABLE ...| lay, set Please lay the table for six.

\section{alarm noun ...}

VERB + ALARM ...| set I set my alarm for 6.30 .

Looking at such lexicographical descriptions, it has to be said that there is certainly no need to re-invent the wheel - at least, not as far as the description of the facts is concerned. The revolutionary developments in corpus linguistics have made it possible to refine linguistic descriptions made in the pre-computer era and to improve on them. Furthermore, they have underscored the extent to which prefabricated items are used in everyday language. What is new, however, is that the constructionist theories provide a framework for accommodating all of these findings and make it clear that we are always dealing with essentially the same type of linguistic unit. ${ }^{38}$ The usage-based research carried out in the last few decades definitely adds a valuable dimension to our understanding of language and opens up promising perspectives for further research concerning language learning, language processing and storage. ${ }^{39}$

This article set out to show how different types of associations between words or classes of verbs that have been described in different frameworks such as traditional phraseology or valency theory can be represented in terms of constructions. It seems to me that pursuing this line of investigation is very promising indeed and in many ways superior to previous accounts - mostly because it can be shown that we are dealing with only one type of linguistic knowledge - constructions. ${ }^{40}$

It has to be said that through corpus linguistic and cognitive constructionist research both Wittgenstein's (1953/1989: $\left.20^{\mathrm{e}} / 43\right)$ statement that in many cases the "meaning of a word is its use in the language" and Firth's (1957/1968: 179) "You shall know a word by the company it keeps" have been developed further with an unforeseeable degree of explicitness and psychological plausibility. ${ }^{41}$ If we assume that a lot of initial language learning consists in the learning of chunks (Lieven, 2014: 10), then item-based valency constructions may 
well be part of this process. ${ }^{42}$ If we take not only grammar but also word meaning as an emergent property, then we can well imagine word meanings (or some word meanings) to be abstractions based on all the constructions containing the word that a speaker has encountered. The fact that the term construction is used for units that are rather different in size and character is indicative of the fact that it is assumed that all of them have certain properties in common with respect to factors such as storage and their role as "processing units" (Bybee, 2013: 51) in the production and comprehension of sentences. Since construction grammar and usage-based accounts are able to account for the phraseological nature of language they provide a very promising research paradigm and a true alternative to Chomskyan linguistics - in a way in which traditional phraseology and valency theory did not. Of course, it is impossible to say whether in the long run either of these research paradigms will replace or absorb the other, or to what extent basic beliefs underlying the respective approaches will be found to be combinable - from the point of view of foreign language linguistics, however, the evidence definitely points in one direction because in usage-based approaches "[p]atterns, structures, constructions, formulas, phraseology" (Ellis, 2008: 3) are certainly not peripheral. ${ }^{43}$

\section{Acknowledgement}

I would like to thank Susen Faulhaber and Peter Uhrig as well as two anonymous reviewers for their comments on an earlier version of this paper. I am particularly grateful to Thomas Proisl for providing me with the Treebank.info analyses presented in this article.

\section{References}

Altenberg, B., 1998. On the Phraseology of Spoken English: The Evidence of Recurrent WordCombinations. In: Phraseology: Theory, Analysis and Applications, Cowie, A.P. (Ed.), Clarendon Press, Oxford, ISBN-10: 0198294255, pp: 101-122.

Ambridge, B. and E. Lieven, 2011. Child Language Acquisition: Contrasting Theoretical Approaches. 1st Edn., Cambridge University Press, Cambridge, pp: 448.

Beckner, C., R. Blythe, J. Bybee, M.H. Christiansen and W. Croft et al., 2009. Language is a complex adaptive system: Position Paper. Lang. Learn., 59: $1-26$.

Behrens, H., 2007. The Acquisition of Argument Structure. In: Valency: Theoretical, Descriptive and Cognitive Issues, Herbst, T. and K. Götz-Votteler (Eds.), Walter de Gruyter, Berlin, ISBN-10: 3110198770, pp. 193-214.
Behrens, H., 2009. Usage-based and emergentist approaches to language acquisition. Linguistics, 47: 383-411. DOI: 10.1515/LING.2009.014

Behrens, H., 2011. Grammatik und Lexikon im Spracherwerb: Konstruktionsprozesse. In: Sprachliches Wissen Zwischen Lexikon und Grammatik, Holler, A. and K. Proost (Eds.), Mouton de Gruyter, New York, ISBN-10: 3110262339, pp: 375-396.

Boas, H.C., 2003. A Constructional Approach to Resultatives. 2nd Edn., CSLI Publications, Stanford, ISBN-10: 1575864088, pp: 400.

Boas, H.C., 2011. Zum Abstraktionsgrad von Resultativkonstruktionen. In: Sprachliches Wissen Zwischen Lexikon und Grammatik, Holler, A. and K. Proost (Eds.), Mouton de Gruyter, New York, ISBN-10: 3110262339, pp: 37-69.

Boas, H.C., 2013. Cognitive Construction Grammar. In: The Oxford Handbook of Construction Grammar, Hoffmann, T. and G. Trousdale (Eds.), Oxford University Press, Oxford, ISBN-10: 0195396685, pp: 233-252.

Bühler, K., 1934. Sprachtheorie: Die Darstellungsfunktion Der Sprache. 1st Edn., Verlag von Gustav Fischer, Jena, pp: 434.

Bybee, J., 2010. Language, Usage and Cognition. 1st Edn., Cambridge University Press, Cambridge, ISBN-10: 0521616832, pp: 264.

Bybee, J., 2013. Usage-based Theory and Exemplar Representation of Constructions. In: The Oxford Handbook of Construction Grammar, Hoffmann, T. and G. Trousdale (Eds.), Oxford University Press, Oxford, ISBN-10: 0195396685, pp: 49-69.

Chomsky, N., 1986. Knowledge of Language: Its Nature, Origin and Use. 1st Edn., Praeger, New York, ISBN-10: 0030055520, pp: 307.

Cowie, A.P. 1994. Phraseology. In: The Encyclopedia of Language and Linguistics, Asher, R.E. and J.M.Y. Simpson (Eds.), Pergamon Press, Oxford, pp: 3168-3171.

Cowie, A.P. and R. Mackin, 1975. Oxford Dictionary of Current Idiomatic English. Oxford University Press, London, ISBN-10: 3810906050, pp: 476.

Cowie, A.P., R. Mackin and I.R. McCaig, 1983. Oxford Dictionary of Current Idiomatic English. 1st Edn., Oxford University Press, Oxford, ISBN-10: 0194311503, pp: 752.

Croft, W. and D.A. Cruse, 2004. Cognitive Linguistics. Cambridge University Press, Cambridge, ISBN-10: 0521667704, pp: 356.

Croft, W., 2003. Lexical Rules vs. Constructions: A False Dichotomy. In: Motivation in Language: Studies in Honor of Günter Radden, Cuyckens, H., T. Berg, R. Dirven and K.U. Panther (Eds.), John Benjamins Publishing Company, Amsterdam and Philadelphia, ISBN-10: 9027275289, pp: 49-68. 
Croft, W., 2013. Radical Construction Grammar. In: The Oxford Handbook of Construction Grammar, Hoffmann, T. and G. Trousdale (Eds.), Oxford University Press, Oxford, ISBN-10: 0195396685, pp: 211-232.

Cruse, D.A., 1986. Lexical Semantics. Cambridge University Press, Cambridge, ISBN-10: 0521276438, pp: 310 .

Dąbrowska, E., 2014. Recycling utterances: A speaker's guide to sentence processing. Cognitive Linguist., 25: 617-653. DOI: $10.1515 / \operatorname{cog}-2014-0057$

De Cock, S., 2000. Repetitive Phrasal Chunkiness and Advanced EFL Speech and Writing. In: Corpus Linguistics and Linguistic Theory, Mair, C. and M. Hundt (Eds.), Rodopi, Amsterdam/Atlanta, ISBN-10: 9042014938, pp: 51-68.

Ellis, N., 2003a. Constructions, Chunking and Connectionism: The Emergence of Second Language Structure. In: The Handbook of Second Language Acquisition, Doughty, C.J. and M.H. Long (Eds.), Wiley, Malden, ISBN-10: 0631217541, pp: 63-103.

Ellis, N., 2003b. Phraseology: The Periphery and the Heart of Language. In: Phraseology in Foreign Language Learning and Teaching, Meunier, F. and S. Granger (Eds.), Benjamins, Amsterdam/Philadelphia, pp: 1-13.

Ellis, N., E. Frey and I. Jalkanen, 2009. The Psycholinguistic Reality of Collocation and Semantic Prosody (1): Lexical Access. In: Exploring the Lexis-Grammar Interface, Römer, U. and R. Schulze (Eds.), John Benjamins Publishing, Amsterdam, ISBN-10: 9027223092, pp: 89-114.

Engel, U., 1977. Syntax der Deutschen Gegenwartssprache. 1st Edn., Schmidt, Berlin, ISBN-10: 3503012516, pp: 307.

Engelberg, S., S. König, K. Proost and E. Winkler, 2011. Argumentstrukturmuster als Konstruktionen? Identität - Verwandtschaft Idiosynkrasien. In: Sprachliches Wissen zwischen Lexikon und Grammatik, Engelberg, S., A. Holler and K. Proost (Eds.), Walter de Gruyter, ISBN10: 3110262339, pp: 71-112.

Faulhaber, S., 2011a. Verb Valency Patterns: A Challenge for Semantics-Based Accounts. 1st Edn., Walter de Gruyter, Berlin, ISBN-10: 3110240785 , pp: 372 .

Faulhaber, S., 2011b. Idiosyncrasy in verb valency patterns. Zeitschrift für Anglistik und Amerikanistik, 59: 347-367. DOI: 10.1515/zaa-2011-0405

Faulhaber, S., T. Herbst and P. Uhrig, 2013. Funktionswortklassen im Englischen: Linguistische und lexikographische Perspektiven. In: Funktionswörter|buch|forschung, Germanistische Linguistik, pp: 59-110.
Fillmore, C., 1988. The Mechanisms of "Construction Grammar". In: General Session and Parasession on Grammaticalization, Axmaker, S., A. Jassier and H. Singmaster (Eds.), Berkeley Linguistics Society, Berkeley, pp: 35-55.

Fillmore, C., 2007. Valency Issues in FrameNet. In: Valency: Theoretical, Descriptive and Cognitive Issues, Herbst, T. and K. Götz-Votteler (Eds.), Mouton de Gruyter, New York, ISBN-10: 3110198770, pp: 129-160.

Fillmore, C., P. Kay and C.M. O’Connor, 1988. Regularity and idiomaticity in grammatical constructions: The case of let alone. Language, 64: 501-538. DOI: $10.2307 / 414531$

Firth, J.R., 1957. Modes of Meaning. In: Papers in Linguistics 1934-51, Oxford University Press, London, pp: 190-215.

Firth, J.R., 1957/1968. A synopsis of Linguistic Theory. In: Selected Papers of J R Firth 1952-59, Palmer, F. (Ed.), Longmans, London and Harlow, pp: 168-205.

Fischer, K. and A. Stefanowitsch, 2006. Konstruktionsgrammatik: Ein Überblick. In: Konstruktionsgrammatik: Von der Anwendung zur Theorie, Fischer, K. and A. Stefanowitsch (Eds.), Stauffenburg, Tübingen, pp: 1-17.

Francis, G., S. Hunston and E. Manning, 1996. Collins Cobuild Grammar Patterns. 1st Edn., Collins CoBUILD, ISBN-10: 0003750515, pp: 512.

Gilquin, G., 2007. To err is not all: What corpus and elicitation can reveal about the use of collocations by learners. Zeitschrift für Anglistik und Amerikanistik, 55: 273-291. DOI: 10.1515/zaa.2007.55.3.273

Gläser, R., 1990. Phraseologie der englischen Sprache. 1st Edn., Enzyklopädie, Leipzig, ISBN-10: 3324000084, pp: 201.

Goldberg, A.E. and R. Jackendoff, 2004. The English resultative as a family of constructions. Language, 80: 532-568. DOI: 10.1353/lan.2004.0129

Goldberg, A.E., 1995. Constructions: A Construction Grammar Approach to Argument Structure. 1st Edn., Chicago University Press, Chicago, ISBN-10: 0226300862, pp: 265.

Goldberg, A.E., 2006. Constructions at Work: The Nature of Generalization in Language. 1st Edn., Oxford University Press, New York, ISBN-10: 0199268517, pp: 280.

Goldberg, A.E., 2013. Constructionist Approaches. In: The Oxford Handbook of Construction Grammar, Hoffmann, T. and G. Trousdale (Eds.), Oxford University Press, Oxford, ISBN-10: 0195396685, pp: 15-31.

Gouws, R.H., 2010. Fixed word Combinations as Second level Treatment units in Dictionaries. In: Feste Wortverbindungen und Lexikographie, Durčo, P. (Ed.), Walter de Gruyter, Berlin, ISBN-10: 3110234068, pp: 51-63. 
Granger, S. and F. Meunier, 2008. Phraseology in Language Learning and Teaching: Where to from Here? In: Phraseology: An Interdisciplinary Perspective, Granger, S. and F. Meunier (Eds.), John Benjamins Publishing, Amsterdam/Philadelphia, ISBN-10: 9027232466, pp: 247-252.

Granger, S. and M. Paquot, 2008. Disentangling the Phraseological Web. In: Phraseology: An Interdisciplinary Perspective, Granger, S. and F. Meunier (Eds.), John Benjamins Publishing, Amsterdam/Philadelphia, ISBN-10: 9027232466, pp: $37-49$.

Granger, S., 1998. Prefabricated Patterns in Advanced EFL Writing: Collocations and Formulae. In: Phraseology: Theory, Analysis and Applications: Theory, Analysis and Applications, Cowie, A.P. (Ed.), Clarendon Press, Oxford, ISBN-10: 0191584746, pp: 145-160.

Gries, S., 2008. Phraseology and Linguistic Theory. In: Phraseology: An Interdisciplinary Perspective, Granger, S. and F. Meunier (Eds.), John Benjamins Publishing, Amsterdam/Philadelphia, ISBN-10: 9027232466, pp: 3-35.

Gries, S.T. and S. Wulff, 2005. Do foreign learners have constructions? Evidence from priming, sorting and corpora. Annual Rev. Cognitive Linguist., 3: 182-200. DOI: 10.1075/arcl.3.10gri

Handl, S., 2008. Essential Collocations for Learners of English: The Role of Collocational Direction and Weight. In: Phraseology in Foreign Language Learning and Teaching, Meunier, F. and S. Granger (Eds.), John Benjamins Publishing, Amsterdam, ISBN-10: 902723244X, pp: 43-66.

Haugen, T.A., 2012. Polyvalent Adjectives in Norwegian: Aspects of their Semantics and Complementation Patterns. University of Oslo.

Hausmann, F.J., 1984. Wortschatzlernen ist Kollokationslernen. Praxis des Neusprachlichen Unterrichts, 31: 395-406.

Hausmann, F.J., 1985. Kollokationen im Deutschen Wörterbuch: Ein Beitrag zur Theorie des Lexikographischen Beispiels. In: Lexikographie und Grammatik, Bergenholtz, H. and J. Mugdan (Eds.), Niemeyer, Tübingen, pp: 118-129.

Hausmann, F.J., 2007. Die kollokationen im rahmen der phraseologie-systematische und historische darstellung. Zeitschrift für Anglistik und Amerikanistik, 55: 217-235.

Helbig, G. and W. Schenkel, 1973. Wörterbuch zur Valenz und Distribution deutscher Verben. 1st Edn., Enzyklopädie. Leipzig.

Herbst, T. and B. Mittmann, 2008. Collocation in English Dictionaries at the Beginning of the Twenty-First Century. Proceedings of the International Annual for Lexicography, (IAL' 08), Niemeyer, Tübingen, pp: 103-119.
Herbst, T. and M. Klotz, 2003. Lexikografie. 1st Edn., Ferdinand Schöningh, Paderborn, ISBN-10: 3506970151, pp: 320.

Herbst, T. and S. Schüller, 2008. Introduction to Syntactic Analysis: A Valency Approach. 1st Edn., Narr, Tübingen, ISBN-10: 3823363905, pp: 212.

Herbst, T., 1996. What are collocations: Sandy beaches or false teeth? English Stud., 77: 379-393. DOI: $10.1080 / 00138389608599038$

Herbst, T., 2011a. Choosing Sandy Beaches: Collocations, Probabemes and the Idiom Principle. In: The Phraseological View of Language: A Tribute to John Sinclair, Herbst, T., S. Faulhaber and P. Uhrig (Eds.), de Gruyter Mouton, Berlin, ISBN-10: 3110257017, pp: 27-57.

Herbst, T., 2011b. The status of generalizations: Valency and argument structure constructions. Zeitschrift für Anglistik und Amerikanistik, 59: 347-367.

DOI: 10.1515/zaa-2011-0406

Herbst, T., 2013. Von Fledermäusen, die auch Schläger sind, und von Gerundien, die es besser nicht gäbe. In: Sprachwissenschaft - Fremdsprachendidaktik: Neue Impulse, Bürgel, C. and D. Siepmann (Eds.), Schneider, Hohengehren, pp: 57-66.

Herbst, T., 2014a. The Valency Approach to Argument Structure Constructions. In: Constructions Collocations Patterns, Herbst, T., H.J. Schmid and S. Faulhaber (Eds.), de Gruyter Mouton, New York, ISBN-10: 3110356104, pp: 159-207.

Herbst, T., 2014b. Idiosyncrasies and Generalizations: Argument Structure, Semantic Roles and the Valency Realization Principle. In: Yearbook of the German Cognitive Linguistics Association, Jahrbuch der Deutschen Gesellschaft für Kognitive Linguistik, Hilpert, M. and S. Flach (Eds.), de Gruyter Mouton, Berlin/München/Boston, pp: 253-289.

Herbst, T., D. Heath, I. Roe and D. Götz, 2004. A Valency Dictionary of English. 1st Edn., Mouton de Gruyter, Berlin and New York, ISBN-10: 3110171945, pp: 961.

Herbst, T., forthc. Foreign Language Learning is Construction Learning: Principles of Pedagogic Construction Grammar. In: Constructionist Approaches to Second Language Acquisition and Foreign Language Teaching, De Knop, S. and G. Gilquin (Eds.).

Hoffmann, T., forthc. Cognitive sociolinguistic aspects of football chants: The role of social and physical context in usage-based construction grammar. Zeitschrift für Anglistik und Amerikanistik.

Howarth, P., 1998. The Phraseology of Learners' Academic Writing. In: Phraseology: Theory, Analysis and Applications, Cowie, A.P. (Ed.), Clarendon Press, Oxford, ISBN-10: 0191584746, pp: 161-186. 
Hunston, S., 2002. Corpora in Applied Linguistics. 1st Edn., Cambridge University Press, Cambridge, ISBN-10: 3125340500, pp: 241.

Hunston, S., 2009. The Usefulness of Corpus-Based Descriptions of English for Learners: The Case of Relative Frequency. In: Corpora and Language Teaching, Aijmer, K. (Ed.), Benjamins, Amsterdam/Philadelphia, ISBN-10: 9027289980 , pp: 141-154.

Hunston, S., 2014. Pattern Grammar in Context. In: Constructions Collocations Patterns, Herbst, T., H.J. Schmid and S. Faulhaber (Eds.), de Gruyter Mouton, Berlin and Boston, ISBN-10: 3110356104, pp: 99-119.

Langacker, R., 1987. Foundations of Cognitive Grammar. 1st Edn., Stanford University Press, Stanford, pp: 1105.

Langacker, R.W., 2008a. Cognitive Grammar: A Basic Introduction. 1st Edn., Oxford University Press, Oxford, ISBN-10: 9780195331967, pp: 584.

Langacker, R.W., 2008b. The Relevance of Cognitive Grammar for Language Pedagogy. In: Cognitive Approaches to Pedagogical Grammar, De Knop, S. and T. Rycker (Eds.), de Gruyter, Berlin, ISBN-10: 3110205386, pp: 7-35.

LDOCE, 2015, Longman English Dictionary online LDOCE.

LDOCE5, 2009. Longman dictionary of contemporary English. Mayor, M. (Ed.). Pearson Longman, Harlow.

LDOCE6, 2014. Longman dictionary of contemporary English. 6th Edn., Pearson. Harlow.

Lea, D., 2007. Making a collocations dictionary. Zeitschrift für Anglistik und Amerikanistik, 55: 261-271.

Lieven, E., 2014. First Language Learning from a Usage-Based Approach. In: Constructions Collocations Patterns, Herbst, T., H.J. Schmid and S. Faulhaber (Eds.), de Gruyter Mouton, Berlin and Boston, ISBN-10: 3110356104, pp: 1-24.

Lipka, L., 1992. An Outline of English Lexicology. 1st Edn., Niemeyer, Tübingen.

Macmillan

Dictionary. $\mathrm{http}: / /$ www.macmillandictionary.com/

MacWhinney, B., 2000. The CHILDES Project: Tools for Analyzing Talk. 3rd Edn., Lawrence Erlbaum Associates, Mahwah, NJ.

MacWhinney, B., 2005. A Unified Model of Language Acquisition. In: Handbook of Bilingualism: Psycholinguistic Approaches, Kroll, J.F. and A.M.B. De Groot (Eds), Oxford University Press, Oxford, pp: 49-67.

Mel'čuk, I., 2003. Les collocations: definition, rôle et utilité. In: Les collocations: analyse and traitement, Grossmann, F. and A. Tutin (Eds.), De Werelt, Amsterdam, pp: 23-31.
Mittmann, B., 2004. Mehrwort-Cluster in der englischen Alltagskonversation: Unterschiede zwischen britischem und amerikanischem gesprochenen Englisch als Indikatoren für den präfabrizierten Charakter der Sprache. 1st Edn., Narr, Tübingen, ISBN-10: 3823360892, pp: 407.

Mittmann, B., 2011. Prefabs in spoken English. The Phraseological View of Language. A Tribute to John Sinclair, Herbst, T., S. Faulhaber and P. Uhrig (Eds.) de Gruyter Mouton, Berlin/Boston, pp: 197-210.

Mollet, E., A. Wray and T. Fitzpatrick, 2014. Accessing second-order collocation through lexical cooccurrence networks. In: The Phraseological View of Language. A Tribute to John Sinclair, Herbst, T., S. Faulhaber and P. Uhrig (Eds.), De Gruyter Mouton, Berlin and Boston, pp: 87-121.

Nesselhauf, N., 2005. Collocations in a Learner Corpus. 1st Edn., John Benjamins, Amsterdam, ISBN-10: 9027222851, pp: 331.

Palmer, F., 1981. Semantics. 2nd Edn., Cambridge University Press, Cambridge.

Pawley, A. and F. H. Syder, 1983. Two Puzzles for Linguistic Theory: Nativelike Selection and Nativelike Fluency. In: Language and Communication, Richards, J.C. and R.W. Schmidt (Eds.), Longman, London, pp: 191-226.

PONS Großwörterbuch für Experten und Universität Englisch-Deutsch Deutsch-Englisch. 2002. Stuttgart: Klett

Proisl, T. and P. Uhrig, 2012. Proceedings of the Eighth International Conference on Language Resources and Evaluation, European Language Resources Association (ELRA), Istanbul, pp: 2750-2756.

Quirk, R., S. Greenbaum, G. Leech and J. Svartvik, 1985. A Comprehensive grammar of the English language. 1st Edn., Longman, London, ISBN-10: 0582517346, pp: 1792.

Rohde, A., 2009. Input Frequency and the Acquisition of the Progressive. In: Input Matters in SLA, Piske, T. and M. Young-Scholten (Eds.), Multilingual Matters, Bristol, ISBN-10: 1847691099, pp: 29-46.

Schmid, H.J., 2003. Collocation: Hard to pin down, but bloody useful. Zeitschrift für Anglistik und Amerikanistik, 51: 235-258.

Schmid, H.J., 2014. Lexico-Grammatical Patterns, Pragmatic Associations and Discourse Frequency. In: Constructions Collocations Patterns, Herbst, T., H.J. Schmid and S. Faulhaber (Eds.), de Gruyter Mouton, Berlin and Boston, ISBN-10: 3110356104 , pp. 239-293.

Schumacher, H., 2004. VALBU - Valenzwörterbuch deutscher Verben. Gunter Narr Verlag, Tübingen, ISBN-10: 3823360647, pp: 1040. 
Siepmann, D., 2005. Collocation, colligation and encoding dictionaries. Part II: Lexicographical aspects. Int. J. Lexicography, 18: 409-444. DOI: $10.1093 / \mathrm{ijl} / \mathrm{eci051}$

Sinclair, J., 1991. Corpus, Concordance, Collocation. 3rd Edn., Oxford University Press, Oxford, ISBN-10: 0194371441, pp: 179.

Sinclair, J., 1999. The computer, the corpus and the theory of language. LMS lingua 1999.1, pp. 21-31 and In Transiti Linguistici e Culturati, Vol 2, G. Azzaro and M. Ulrych (eds), Trieste: EUT, pp. 1-15.

Sinclair, J., 2004a. Trust the Text: Language, Corpus and Discourse. 1st Edn., Routledge, London, ISBN-10: 020359407X, pp: 224.

Sinclair, J., 2004b. Intuition and annotation - the discussion continues. In: Advances in Corpus Linguistics, Aijmer, K. and B. Altenberg (Eds.), Rodopi, Amsterdam, ISBN-10: 9042017414, pp: 39-51.

Sinclair, J.M. and A. Mauranen, 2006. Linear Unit Grammar. 1st Edn., John Benjamins Publishing, Amsterdam, ISBN-10: 9027222983, pp: 185.

Stefanowitsch, A. and S.T. Gries, 2003. Collostructions: Investigating the interaction of words and constructions. Int. J. Corpus Linguist., 8: 209-243. DOI: $10.1075 / \mathrm{ijcl} .8 .2 .03 \mathrm{ste}$

Stefanowitsch, A., 2011a. Keine Grammatik ohne Konstruktionen: Ein logisch-ökonomisches Argument für die Konstruktionsgrammatik. In: Sprachliches Wissen Zwischen Lexikon und Grammatik, Holler, A. and K. Proost (Eds.), Mouton de Gruyter, Berlin and New York, ISBN-10: 3110262339, pp: 181-210.

Stefanowitsch, A., 2011b. Argument structure: Itembased or distributed? Zeitschrift für Anglistik und Amerikanistik 59: 369-386.

DOI: 10.1515/zaa-2011-0407

Stefanowitsch, A., 2014. Collostructural analysis: A case study of the English into-causative. In: Constructions Collocations Patterns, Herbst, T., H.J. Schmid and S. Faulhaber (Eds.), de Gruyter Mouton, Berlin and Boston, ISBN-10: 3110356104 , pp. 217-238.

Tesnière, L., 1959. Éléments de syntaxe structurale. 1st Edn., Klincksieck, Paris, pp: 670.

Tomasello, M., 2003. Constructing a Language. 1st Edn., Harvard University Press, Cambridge, Mass. and London.

Uhrig, P. and T. Proisl, 2012. Less hay, more needles using dependency-annotated corpora to provide lexicographers with more accurate lists of collocation candidates. Lexicographica, 28: 141-180. DOI: 10.1515/lexi.2012-0009

Uhrig, P. and T. Proisl. 2011. Treebank.info. www.treebank.info
Verspoor, M. and H. Behrens, 2011. Dynamic Systems Theory and a Usage-Based Approach to Second Language Development. In: A Dynamic Approach to Second Language Development: Methods and Techniques, Verspoor, M.H., K. de Bot and W. Lowie (Eds.), Benjamins, Amsterdam/Philadelphia, ISBN-10: 902728735X, pp: 25-38.

Verspoor, M., W. Lowie and K. de Bot. 2009. Input and Second Language Development from a Dynamic Perspective. In: Input Matters in SLA, Piske, T. and M. Young-Scholten (Eds.), Multilingual Matters, Bristol, ISBN-10:1847691099, pp: 62-80.

Welke, K., 2011. Valenzgrammatik des Deutschen: Eine Einführung. 1st Edn., Walter de Gruyter, Berlin, ISBN-10: 3110195380, pp: 343.

Wittgenstein, L., 1953. Philosophical Investigations. 3rd Edn., Blackwell, Oxford.

Young-Scholten, M. and T. Piske, 2009. Introduction. In: Input Matters in SLA, Piske, T. and M. YoungScholten (Eds.), Multilingual Matters, Bristol, ISBN-10: 1847691099, pp: 1-26.

1 Referring to these different approaches as generative grammar on the one hand and construction grammar on the other is a gross oversimplification, of course. Firstly, some construction grammarians also claim to be "generative" (see Fischer and Stefanowitsch, 2006: 89.); secondly, there are considerable differences between various types of construction grammar; thirdly, constructions are only a part of the research domain of cognitive linguistics.

2 Compare also Fillmore et al., (1988: 534).

3 See, for example, Palmer (1981: 80). Compare also Gläser (1990: 54-61). For a typology of phraseological units see also Granger and Paquot (2008).

4 For a very similar definition see Cowie and Mackin (1975: viii).

5 See also Goldberg and Jackendoff (2004: 539) and Boas (2003).

6 Compare also the following figures from COCA: drive $\forall$ *** crazy: 1088 (per million words); drive $\forall * * *$ mad: 142 (pmw); drive $\forall * * *$ nuts: 354 (pmw). The same search in the BNC produces a preference for mad:: drive $\forall * * *$ crazy: 71 (0.72 pmw) drive $\forall * * *$ mad: 115 (1.17 pmw); drive $\forall$ *** nuts: 18 ( $0.18 \mathrm{pmw})$.

7

For a discussion of the Resultative Construction and the Intransitive Resultative Construction see Goldberg (1995: 79).

8 Furthermore, no instances of make *** up the wall can be found in the BNC or in COCA. For the relationship of idioms and general paterns see Goldberg (2006: 55). For networks and inheritance relationships see also Boas (2013: 244-246). 
9 When used with the indefinite article, however, early bird may be used neutrally in this respect as in: Are you a nightowl or an early bird? <COCA: $2006 \mathrm{MAG}>$

10 Example taken from the ITV series Lewis series 5 (Old, unhappy, far off things): ITV Studios Ltd. 2010, Edel Germany GmbH 2013.

11 See also Sinclair (2004a: 29-30) and Hunston (2009: 142143).

12 See also Sinclair (1999: 30) and Hunston (2002: 101-102).

13 The form brinks occurs twice in the BNC, one of these occurrences is a name and 70 times in COCA, of which only four are not the name. I give absolute figures of occurrence here to show the relation in the different uses within each corpus (BNC: almost 100 million words, COCA 450 million words).

14 See also the accounts of valency in terms of patterns: e.g. Engel (1977: 80-81), VALBU (2004: 941-993) or the pattern grammar approach (Francis et al., 1996; Hunston, 2014). Compare also the valence information provided by FrameNet (Fillmore, 2007).

15 This definition bears a striking resemblance to the famous statement by Bühler (1934: 173) words of particular word classes open up slots which have to be filled by other word classes: "dass die Wörter einer bestimmten Wortklasse eine oder mehrere Leerstellen um sich eröffnen, die durch Wörter anderer Wortklassen ausgefüllt werden müssen."

16 For similar concepts such as mini-constructions or verb(class-)specific constructions see Boas (2003; 2011: 47-55) and Croft (2003: 56-62). For the relationship of valency constructions and the kind of argument structure constructions discussed by Goldberg $(1995 ; 2006)$ see Herbst $(2011 b ; 2014 a ; 2014 b)$. For the item-specific character of valency properties see also Faulhaber (2011ab). Compare also Stefanowitsch (2011b).

17 These are the nouns occurring in a range of R1-R3 in a BNC search of the type $\{$ meet $/ \mathrm{V}\}$.

18 These figures refer to the nouns occurring as heads of object NPs in this construction. Log-likelihood calculation by $\mathrm{T}$. Proisl (FAU). Note that in terms of absolute frequency, the following pronouns fall within the frequency range of the nouns listed: it (326), him (313), her (221), them (217), me (158), you (119), one (80) and us (53). A more sophisticated method of determining the collostructional strength of items appearing in a particular slot of a construction is provided by the approach of collostructional analysis (Stefanowitsch and Gries, 2003; Stefanowitsch, 2014), for the problems of this approach, see, however, Bybee (2010: 97-101). For Treebank.info see also Proisl and Uhrig (2012) and Uhrig and Proisl (2012).

19 For the meaning of crazy ompare e.g.: I said, well, is it crazy to ask the question? <COCA: $2011 \mathrm{SPOK}>$ or And it's crazy to me that I can walk out of my apartment and... $<$ COCA: 2011 NEWS $>$

20 For the relation of the Caused-Motion and Resultative Constructions in terms of "metaphorical exdtension inheritance links" see Goldberg (1995: 88).

21 Search: "drive/verb - xcomp/collo-item/adjective nsu/me|you|him|her|them|us". This search produced a number of further collocates such as hard, uptown or onward, which semantically do not belong to this construction. For a detailed analysis of drive sb crazy see also Boas, 2003: 200, 234-235 and 300-303).

22 There seems to be very little conclusive research on the acquisition of verb or construction meanings directly relevant to this discussion, however. Compare e.g. the discussion of various approaches to the learning of word meanings in Ambridge and Lieven (2011). See also Tomasello (2003: 43-93, esp. 54).

23 There are three main exceptions: Mother: does that mean the man's about to meet his death as well and fall off the table? <CHILDES: Thomas t2 02 13> and two examples of the type: there's a little bit of a hill there where the kitchen floor meets the dining room floor. <CHILDES: Thomas $\mathrm{t} 2$ $0915>$. Furthermore, there are 6 cases of meet up, 3 monovalent uses with plural subject and one so he's a jolly good person for you to meet < CHILDES: Thomas $\mathrm{t} 208$ $00>$.

24 Of the nouns occurring as heads of direct object NPs of meet the following five nouns show the highest loglikelihood value in the $\mathrm{BNC}$ (on the basis of a treebank.info analysis carried out by T. Proisl): need (12488,3507), requirement $(6400,7413)$, demand $(4669,3398)$, criterion $(2227,4551)$ and standard $(2210,2799)$.

25 It is debatable whether words such as cost or expenses should be subsumed under this construction. A comprehensive description of the meaning of meet is not intended here, which would also have to cover sentences such as As with all new ideas it met with resistance ... <BNC: G00 3174>, The working class met even stiffer resistance when they tried to secure political representation through the Chartist Movement. $<\mathrm{BNC}$ : ANY 1146> A contingent headed for Plymouth and met their first serious [...] resistance at Trematon Castle by Saltash, held for the King by Sir Richard Grenville. $<\mathrm{BNC}$ : B0G 682> For a discussion of sense distinctions with meet see also Herbst and Klotz (2003: 37-47). The semantic role 'SUBJECT' is used her in want of a better term for an entity which is related to something else.

26 For discussions of collocation see also Ellis, Frey and Jalkanen (2009), Handl (2008), Hausmann (2007), Herbst (2011a), Mel'čuk, (2003), Mollet et al., (2011), Schmid (2003; 2014) and Siepmann (2005). See also Croft and Cruse (2004: 249-250), who classify collocations as "encoding idioms". For the use of collocations by learners of English see also Gilquin (2007), Granger (1998), Herbst (1996), Howarth (1998), Nesselhauf (2005).

27 For the relationship between idiosyncratic and generalized knowledge see also Goldberg (2006: 63) and Behrens (2007).

28 "Kinder erwerben nicht die Wörter mit ihren Subkategorisierungseigenschaften ..., sondern sie erwerben das Lexikon durch und in den Konstruktionen, in denen sie auftauchen." (Behrens, 2011: 382). See also Lieven (2014: 21).

29 For a more detailed analysis and discussion see Herbst (forthc.).

30 For forms that occur as premodifiers the frequencies are much more levelled: six month, 6-month, 6 month, sixmonths, 6-months: 380 (BNC) and 403 (COCA); half year, half-year: 253 (BNC) and 193 (COCA). 
31 The corpora analysed are the BNC Spoken Demographic Corpus (BNCSD) and the Longman Spoken American Corpus (LSAC). For the data quoted see Mittmann (2004: 152 and 221), where a more detailed description (including e.g. sort a, kind a, sorts of, kinds of) is provided. Bold type indicates a statistically significant difference between the two corpora. Compare also Mittmann (2011).

32 For an outline of such differences from a constructionist point of view see e.g. Ellis (2003: 72-78), Verspoor and Behrens (2011: 30-31) and Beckner et al. (2009: 9-12).

33 For the role of input in second language acquisition see e.g. Young-Scholten and Piske (2009), Rohde (2009) and Verspoor et al., (2009).

34 For the role of constructions in foreign language learning see Gries and Wulff (2005). For the use of chunks by learners see de Cock (2000). For the shortcomings of some teaching materials used at German schools see Herbst (2013, forthc.), for a moderate view concerning the teaching of phraseological units see Granger and Meunier (2008).

35 See e.g. Herbst and Mittmann (2008).

36 Interestingly, the online version of LDOCE6 does not show any great improvement in the search mechanisms for the examples analysed here (accessed April 2015); one major change, however, is that in LDOCE6-online the lemma lists are shown simultaneously with the (presumably most frequent) member of the list.

37 What Gouws (2010: 61) says with respect to print dictionaries also applies to electronic dictionaries: "Fixed expressions are fully-fledged lexical items and should be recognised as such by dictionaries. They deserve macrostructural status and therefore procedures need to be developed to treat them as lemmata."

38 One would probably do many traditional phraseologists an injustice if one were to say that they were totally unaware of cognitive issues. Cowie (1994: 3168), describing the development of phraseology in the 1980s and 1990s, speaks of "a keener awareness than before of ready-made memorized combinations in written and spoken language and a wider recognition of the central part they play in first and second language acquisition and in speech production", Franz-Josef Hausmann's "Wortschatzlernen ist Kollokationslernen" (1984) has learning in the title and also John Sinclair, in the passage quoted at the beginning of this article, talks of the language user having "available to him or her a large number of semi-preconstructed phrases". While such statements entail an ultimate awareness of the fact that language exists in the minds of speakers, these scholars did not explicitly address the cognitive questions involved. Rather, so that the usage-based research carried out in the last few decades definitely adds a valuable dimension. Note, however, that Sinclair and Mauranen (2006: 31-32) emphasize the differences between linear unit grammar and one type of construction grammar, but see also Sinclair and Mauranen (2006: 39-40).

39 For research concerning the storage of chunks see Behrens (2009: 390) See also Dąbrowska (2014).

40 See also Stefanowitsch (2011a: 209-210).

41 For Firth see also Ellis et al., (2009: 109).
42 Compare Behrens (2011: 382): "Kinder erwerben nicht die Wörter mit ihren Subkategorisierungseigenschaften, die dann bestimmen, an welchen syntaktischen Strukturen ein Wort partizipieren kann, sondern sie erwerben das Lexikon durch und in den Konstruktionen, in denen sie auftauchen." (Children do not learn words with selectional restrictions which would then determine in which syntactic structures a word can occur, but they acquire the lexicon through and with the constructions in which they occur. My translation.)

43 For the core-periphery distinction see e.g. Chomsky (1986: 147). For the role of phraseology in generative grammar, cognitive grammar and construction grammar see also Gries (2008). 